\title{
Confirmation of the type locality and the distributional range of Suzukielus sauteri (Opiliones, Cyphophthalmi) in Japan
}

\author{
Gonzalo Giribet ${ }^{1}$, Nobuo Tsurusaki ${ }^{2}$, \& Sarah L. Boyer ${ }^{1}$ \\ ${ }^{1}$ Department of Organismic \& Evolutionary Biology, Museum of Comparative Zoology, \\ Harvard University, 26 Oxford Street, Cambridge, MA 02138, U. S. A. \\ E-mail:ggiribet@oeb.harvard.edu \\ ${ }^{2}$ Laboratory of Biology, Faculty of Regional Sciences, Tottori University, Tottori, 680-8551, Japan \\ E-mail: ntsuru@rstu.jp
}

\begin{abstract}
As a result of a field survey to collect specimens of Suzukielus sauteri, a sironid species endemic to Japan, for molecular and chromosomal study, we confirmed occurrence of the species from six different localities covering the Tokyo, Kanagawa, Yamanashi, and Shizuoka Prefectures. This includes the Yamabushi Pass, near Lake Yamanaka of Yamanashi Prefecture, which enabled us to conclude that the type locality of the species, which has remained ambiguous for a long time, is Lake Yamanaka. All the known records of the species are provided and mapped for the first time.
\end{abstract}

Key words - Distribution, Sironidae, Suzukielus sauteri, type locality

In 1916 Prof. Carl F. Roewer described the first and only Cyphophthalmi from the Japanese archipelago, Miopsalis sauteri Roewer, 1916 from a series of animals collected in "Yamanaka, Suraga [sic], 1100-2000 m" by H. Sauter between 19-25 March 1905. Lectotype (SMF RI/1280) and several paralectotypes (SMF 24979 [ex RI/1280]) (Fig. 1) are reposited at the Senckenberg Museum, Frankfurt. Another series of paralectotypes is deposited at the Zoological Museum, Berlin (ZMB 11490-11494), and one male juvenile without collection data is deposited at the Muséum d'histoire naturelle (MHNG), Genève.

Since the original report, Juberthie (1970) provided a detailed redescription of the species based on re-examination of the type material, and assigned it to its own monotypic genus Suzukielus in the family Sironidae, while Miopsalis belongs to Stylocellidae.

Since its original collection, no reports had been made on the presence of Suzukielus sauteri in Japan until 19 February 1968 when Dr. Jun-ichi Aoki, a leading Japanese soil zoologist and oribatid taxonomist, found 4 specimens (1 male, 2 females and 1 juvenile) of this species in the forest of a small shrine in the Atagawa Spa in the Izu Peninsula, Shizuoka Prefecture (J. Aoki, pers. comm.). These specimens were reported by Suzuki \& Ohrui (1972) with a photo of a female. Besides these specimens, James Cokendolpher had one male and two juveniles in his private collection from Mt. Takao (Tokyo Prefecture), which were originally collected by A. Kosaku on 9 June 1986 and transferred from the second author's collection to J. Cokendolpher; the male was donated to the first author for SEM study, and appeared illustrated in de Bivort \& Giribet (2004). Other than these specimens, only a few more (1 male and 1 juvenile, from Mt. Takao; and 1 male, 1 female, and 4 juveniles from Nakasawa, Minami-Asakawa-cho, near Mt. Takao) were collected by A. Kosaku on 9 June 1986 and are deposited in Tottori University. Furthermore, Suzuki (1975) hinted at the occurrence of the species in Akanezaki Point, Shimoda, in the Izu Peninsula.

Suzukielus sauteri is a rare species in scientific collections, and in fact there are just a few reports other than the ones mentioned above. Aoki (1973) and Tsurusaki (1996) both provided illustrations of this species, in the latter a nice color photograph of a live male by Yosei Minagoshi, renowned Japanese photographer of soil fauna (see also the popular book by Minagoshi 2005). One of the reasons for its scarcity in collections may be the uncertainty about the exact type locality of this species (Giribet 2000). The type series is based upon specimens collected by H. Sauter between 19 and 25 March 1905 in Yamanaka, Suraga [sic]. According to Suzuki \& Ohrui (1972) the type locality is Mount Fuji, and therefore they associated Yamanaka with Lake Yamanaka, located in the northern slopes of Mount Fuji at ca. $900 \mathrm{~m}$ elevation. In his World Catalogue of the Cyphophthalmi, Giribet (2000) argued that Yamanaka may refer to Yamanaka-Shinden in Mishima City of the Shizuoka Prefecture based on a personal communication by $\mathrm{N}$. Tsurusaki because (a) subsequent to the original collection, S. sauteri had never been reported from Mount Fuji or from around Lake Yamanaka, (b) Lake Yamanaka is not within the realm of "Suruga" but in "Kai" in the old 

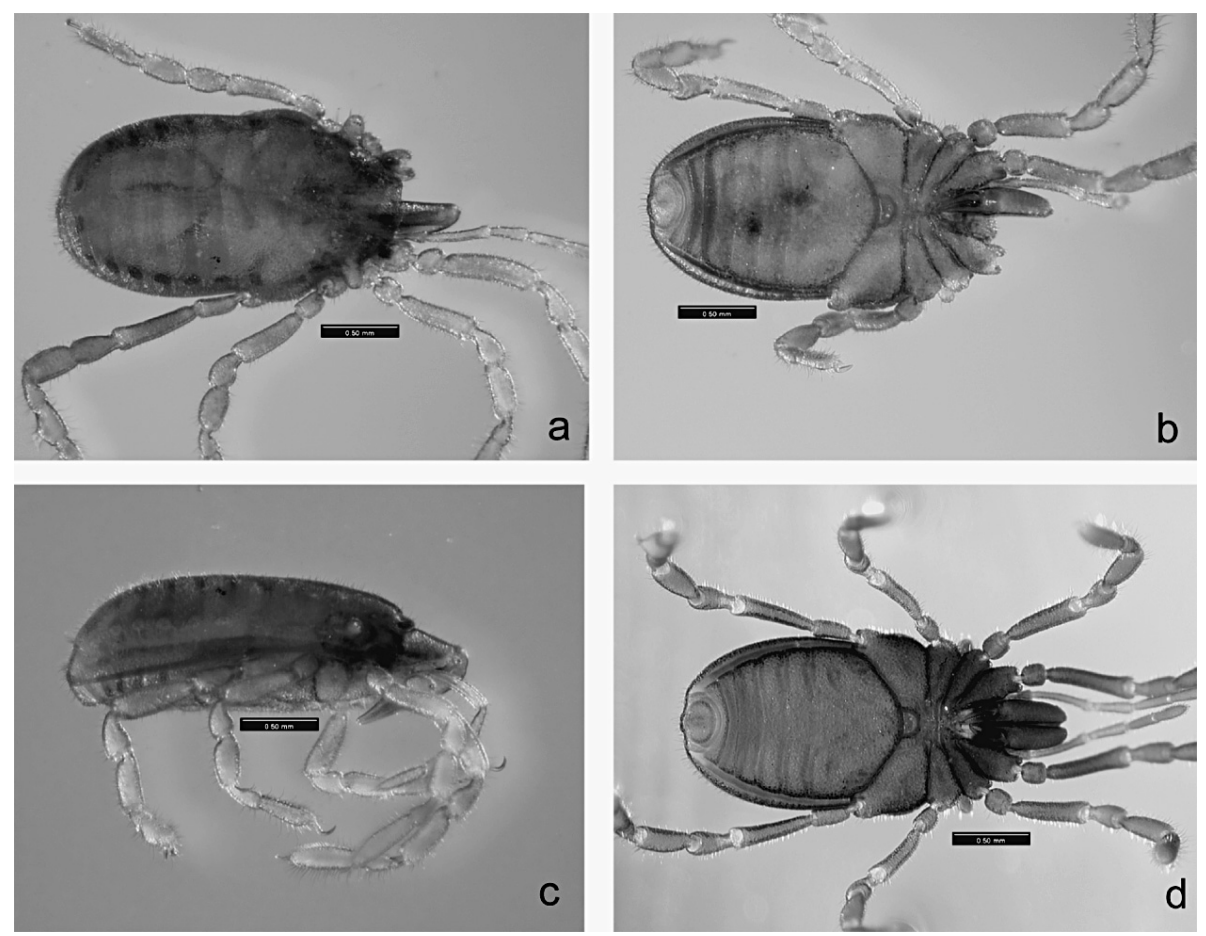

Fig. 1. Suzukielus sauteri: (a) Lectotype (SMF RI/1280) in dorsal view; (b) Same specimen in ventral view. (c) Same specimen in lateral view; (d) Paralectotype (SMF RI/24979) specimen in ventral view. For a color version of these images visit

http://collections.oeb.harvard.edu/Invertebrate/Cyphophthalmi/species.cfm

administrative districts (Suruga corresponds to the northeastern area of Shizuoka Prefecture and Kai to whole area of Yamanashi Prefecture), and (c) the elevation of Lake Yamanaka seemed too high considering the fact that all the newly obtained specimens came from evergreen broadleaved forests growing in the warm temperate zone at lower altitudes of the Izu Peninsula. Yamanaka-Shinden, which was a post station on the old road "Tôkaido" which connected Edo (Tokyo) and Kyoto, is on the southern slope of the Hakone Mountains at an altitude of $550 \mathrm{~m}$. Tsurusaki had got the idea from Dr. Masao Kubota, well known myrmecologist from Odawara, Kanagawa Prefecture.

With the aim of collecting live specimens of $S$. sauteri for molecular and cytogenetic studies, the authors undertook a short collecting trip to the Tokyo, Yamanashi, Kanagawa and Shizuoka Prefectures. The Yamanashi Prefecture localities were chosen nearby Lake Yamanaka to investigate the possibility that this were the true type locality of $S$. sauteri (contra Giribet 2000). Collecting of specimens was done by hand by turning logs and stones, or by sifting leaf litter through a $3 \mathrm{~mm}$ mesh mounted on a canvas bag and inspecting the filtered debris on white trays. The second method tends to yield more specimens than the direct inspection of logs, although this was not the case in all localities.

The expedition yielded specimens of S. sauteri (Fig. 2) in six localities (Fig. 3), where they were rather abundant in different types of mixed forests. Here we report the specimens collected in each locality as well as the precise locality

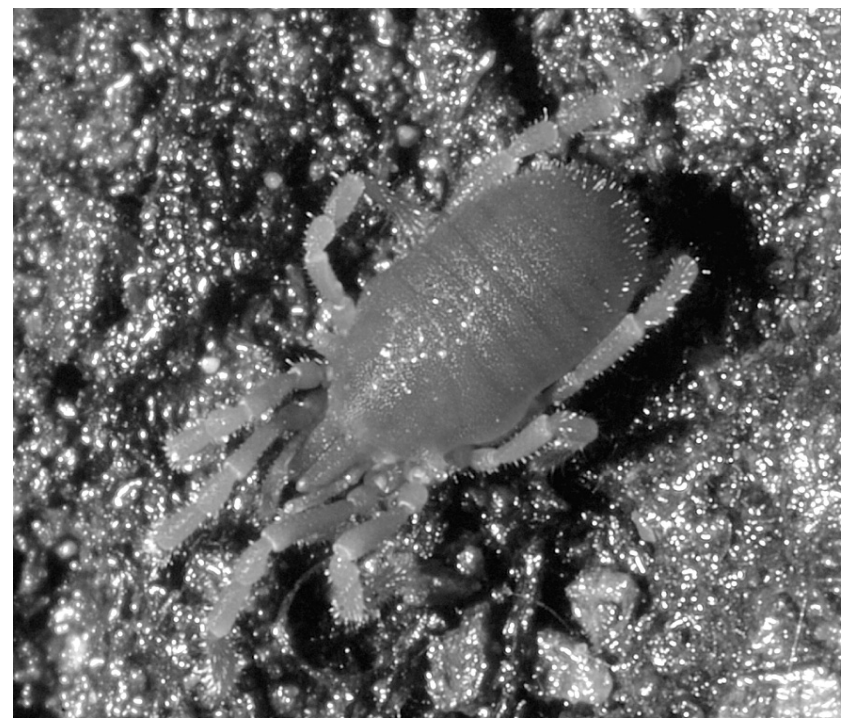

Fig. 2. Male specimen of S. sauteri from Mt. Takao photographed by G. G.

data. The specimens are deposited at the Tsurusaki collection and at the Museum of Comparative Zoology, Department of Invertebrate Zoology under accession numbers MCZ DNA101543 to DNA101550.

\section{Collections}

1) Mt. Takao, Airin Campground (N 35 $38^{\prime} 03^{\prime \prime}$, E $139^{\circ}$ $\left.14^{\prime} 28^{\prime \prime}\right), 294$ m elevation, Hachiôji City, TOKYO PREF., S. 


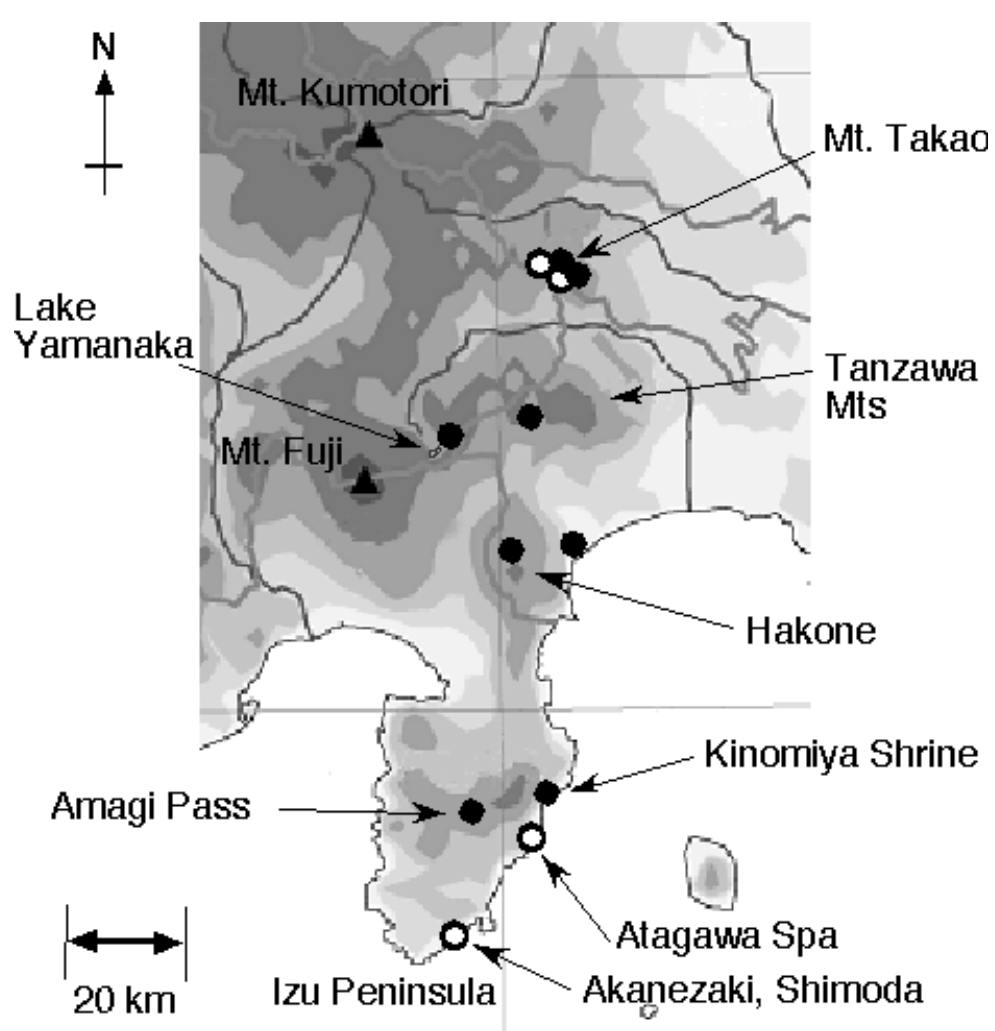

Fig. 3. Localities sampled that yielded specimens of Suzukielus sauteri $(\bigcirc)$ and other known records $(\bigcirc)$.

Boyer, G. Giribet, Y. Minagoshi, N. Tsurusaki, leg., 13 April 2005. 4 males and 4 females (3 males dissected for chromosome preparation); ca. 40 specimens litter sifted and hand collected under logs of Cryptomeria japonica (MCZ DNA101543, DNA101544).

2) Mt. Takao, Umenoki-daira, (N $35^{\circ} 37^{\prime} 25^{\prime \prime}$, E $139^{\circ} 15^{\prime}$ 52"), 181 m elevation, Hachiôji City, TOKYO PREF., S. Boyer, G. Giribet, Y. Minagoshi, N. Tsurusaki, leg., 13 April 2005. 2 males (all for chromosome preparation); ca. 30 specimens litter sifted and hand collected, in mixed forest of Castanea crenata and Quercus serrata (MCZ DNA101545, DNA101546).

3) Yamabushi Pass (N $35^{\circ} 26^{\prime} 57^{\prime \prime}$, E $\left.138^{\circ} 55^{\prime} 41^{\prime \prime}\right)$, near the south entrance of the Yamabushi-Tôge Tunnel, $1076 \mathrm{~m}$ elevation, Yamanakako-mura, YAMANASHI PREF., S. Boyer, G. Giribet, N. Tsurusaki, leg., 14 April 2005. 4 males, 4 females, and 4 juveniles ( 2 males, 1 female, and 2 juveniles for chromosome preparation); 18 specimens in mixed litter of Quercus serrata, Carpinus sp. and Pinus densiflora (MCZ DNA101547).

4) Mt. Daigadake (N $35^{\circ} 14^{\prime} 56^{\prime \prime}$, E $\left.139^{\circ} 01^{\prime} 08^{\prime \prime}\right), 899 \mathrm{~m}$ elevation, Sengokubara, Hakone, KANAGAWA PREF. S. Boyer, G. Giribet, N. Tsurusaki, leg., 14 April 2005. 2 males, 1 female (1 male for chromosome preparation); 21 specimens in mixed litter of Quercus acutissima, $Q$. crispula, and Magnolia obovata (MCZ DNA101548). This locality was visited as per suggestion from Mr. Hiroki Mizushima.

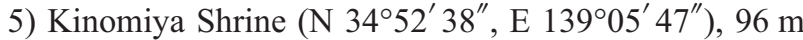
elevation, Yawatano, Ito,. SHIZUOKA PREF. S. Boyer, G. Giribet, N. Tsurusaki, leg., 15 April 2005. 4 males (3 males for chromosome preparation); 31 specimens in mixed litter of Quercus, Castanopsis, and Cryptomeria (MCZ DNA101549).

6) Amagi Pass ( $34^{\circ} 50^{\prime} 00^{\prime \prime}$, E $138^{\circ} 55^{\prime} 54^{\prime \prime}$ ), along a trail to Amagi Pass from the North entrance of the Amagi Tunnel, $\quad 640 \mathrm{~m}$ elevation, Amagi-Yugashima-cho, SHIZUOKA PREF. S. Boyer, G. Giribet, N. Tsurusaki, leg., 15 April 2005. 9 males, 11 females, and 1 juvenile ( 2 males and 2 females for chromosome preparation); 16 specimens litter sifted and hand collected (MCZ DNA101550).

Other than the these localities, we can enumerate the following localities through literature, personal communication, and additional specimens recently provided by Dr. J. Aoki to the second author): TOKYO PREF.: Hachiôji City, Ura-Takao, Mt. Kagenobu, Kogezawa (K. Ito, personal comm.). - KANAGAWA PREF. Yamakita-Machi, NishiTanzawa, 1 male, 23 April 2004, J. Aoki., leg.; Odawara City, Iryuda, Maruyama, 1 female, litter in bamboo forest, 21 May 2005, J. Aoki ,leg.

\section{Discussion}

Suzukielus sauteri has been considered a rare species of Cyphophthalmi, and until now the identity of the type locality remained, to say the least, confusing. In this note we report collections of almost 200 specimens during a collecting 
period of three days along ca. 100 linear $\mathrm{km}$, and ranging from 96 to 1,076 m elevation, including localities near Lake Yamanaka, thus confirming this as its type locality. Cyphophthalmi species generally have restricted distribution ranges in tropical places, although several temperate species have broader distributions spanning a few hundred kilometers. The distribution of Suzukielus sauteri spans ca. $100 \mathrm{~km}$, from the Izu Peninsula (southernmost locality so far known is Akanezaki Point in Shimoda city), at altitudes below $100 \mathrm{~m}$, to altitudes greater than $1000 \mathrm{~m}$ in the FujiHakone-Izu National Park, and north to the Tanzawa Mountains of Kanagawa Prefecture and the Takao Mountains of Tokyo Prefecture (the northernmost record is Mt. Kagenobu, which is located in just north of Mt. Takao). The species is abundant in different types of mixed forests, especially in those with dominance of Fagaceae and Taxodiaceae. In spite of continuous efforts to find Suzukielus sauteri or other Cyphophtalmi in various parts of Japanese Islands for more than 30 years by the second author and many Japanese colleagues who routinely employ a Tullgren apparatus or sifters, to date this area remains the only region of Japan where Cyphophthalmi have been recorded.

\section{Acknowledgments}

We are indebted to Ligia Benavides for generating the Automontage images for Figure 1. We also thank Jun-ichi Aoki, Akinori Kosaku, Ken Ito, and Hiroki Mizushima for providing us information on the localities of Suzukielus sauteri or for providing additional material, and to Jason Dunlop (ZMB), Peter Jäger (SMF), and Peter Schwendinger (MHNG) for loaning Suzukielus material.
Special thanks goes to Yosei Minagoshi who provided us much information on the localities of the species around Mt. Takao and kindly accompanied and guided our field trip to Mt. Takao. This material is based upon work supported by the National Science Foundation under Grant No. 0236871 to G.G. and by a Grant-in-aid for Scientific Research from the Japan Society for the promotion of Science No. 16570076 to N.T.

\section{References}

Aoki, J. 1973. Soil Zoology. An Introduction to Classification and Ecology of Soil Animals. Hokuryu-kan Publishing Co. (Tokyo), 814 pp. (In Japanese)

de Bivort, B.L. \& Giribet, G. 2004. A new genus of cyphophthalmid from the Iberian Peninsula with a phylogenetic analysis of the Sironidae (Arachnida : Opiliones : Cyphophthalmi) and a SEM database of external morphology. Invertebrate Systematics 18, 7-52.

Giribet, G. 2000. Catalogue of the Cyphophthalmi of the world (Arachnida, Opiliones). Revista Ibérica de Aracnologia 2, 49-76.

Juberthie, C. 1970. Sur Suzukielus sauteri (Roewer, 1916) opilion cyphophthalme du Japon. Revue d'Écologie et de Biologie du Sol 7, $563-569$

Minagoshi, Y. 2005. Handbook of Small Creatures in Soil Litter. Bun-ichi Sogo Publishing (Tokyo), 78 pp. (In Japanese)

Roewer, C. F. 1916. 7 neue Opilioniden des Zoolog. Museums in Berlin. Archiv. Naturgesch. 81, 6-13.

Suzuki, S. 1975. Collecting trips to Izu and Amagi. Iden (Tokyo), 29 (4): 82-86. (In Japanese)

Suzuki, S. \& Ohrui, M. 1972. Opiliones of the Izu Peninsula, Central Japan. Acta Arachnologica, 24: 41-50. (In Japanese with English Abstract)

Tsurusaki, N. 1996. Opiliones. pp. 28-30. In: Ishii, M., Ohtani, T., \& Johki, Y. (eds.) The Encyclopaedia of Animals in Japan, Vol. 8 , Insects I, Heibonsha Ltd Publishers (Tokyo), 190 pp. (In Japanese)

Received September 2, 2006 / Accepted September 29, 2006 